\title{
Prospects of using innovations in post-pandemic higher education
}

\author{
Andrey Aleksandrovich Konkin", Svetlana Yurievna Dronova, Galina Viktorovna \\ Tretyakova, Aleksey Eduardovich Bermudez-Alekina, and Vladimir Viktorovich Kotenko \\ Financial University under the Government of the Russian Federation, Department of Foreign \\ Languages and Intercultural Communication, Moscow, Russia
}

\begin{abstract}
The prerequisites of this study were the practices of using innovative educational methods and technologies in higher education during the global COVID-19 pandemic, as well as their potential prospects for using already in the post-pandemic period. The purpose of the study was to assess the prospects and give innovative forecasts used in the framework of distance learning in post-pandemic higher education. To achieve this goal, such methods were used: analysis, inductive-deductive method, comparison method, as well as experimental and forecasting methods. The main result of the study is the conclusion that the prospects for using innovations of the pandemic period in post-pandemic higher education take place mainly in organizing the educational process in a hybrid (or a mixed) format, which involves the simultaneous use of traditional and innovative teaching methods and technologies. At the same time, among the innovative educational technologies that emerged during the pandemic and promising in the post-pandemic period, the following aspects were identified: remote lectures; remote seminars using online whiteboards, online video conferences, virtual and augmented reality technologies; interactive online learning technologies; remote technologies for organizing the educational process. Traditional educational technologies, in turn, included the following: personal consultations with a teacher; personal communication with a supervisor on student research papers; interactive practical classes, as well as a number of other technologies that are built on direct communication between students within a group or on communication between students and a teacher.

Keywords: COVID-19, distance education, innovative educational technologies, online education, hybrid learning format, mixed learning format, interactive whiteboard
\end{abstract}

\section{Introduction}

In the forced transition of higher education to distance learning during the coronavirus pandemic, universities and teachers faced the need to revise the usual format of classes, using the latest technologies, both technical and methodological, to preserve the

\footnotetext{
*Corresponding author: a akonkin@fa.ru
} 
effectiveness of the educational process and adapt as soon as possible to the conditions and requirements of modernity [1, 2]. Carbonell [3] defines innovation in pedagogy as measures, decisions and processes carried out with a certain degree of awareness and consistency, aimed at changing approaches, ideas, cultures, content, models and pedagogical practices. Innovative technologies in higher education represent a new educational space and provide opportunities for effective individual and group learning [4], which should be used in the future [5]. Computer technologies are not so much tools, means, resources, as platforms for interaction and innovative educational experience [6]. At the same time, many researchers note that modern educational technologies should be based on the principles of globalization, inter- and transdiciplinarity, proceed from active learning, project-based learning, a competence-based approach and a case study [7-13].

The use of ICT in education is widespread and its effectiveness has been proven, however, at the beginning of 2020, teachers and students had to master not just ICT in education, but a new learning format - distance learning, although it is noted that in the first months, rather than distance learning was practiced, but an attempt to transfer the full-time format of classes to distance learning [14], which was ineffective [15] and caused "Zoom Fatigue" [16].

According to the study conducted among Irish teachers, the interactive whiteboard, Microsoft Teams and OneNote, Zoom, Google classrooms are most often used during the pandemic [17]. The results of another study show that education is the second most frequently used group of digital technologies after medicine, and video calling platforms are most often used, as well as the GitHub repository, Blackboard, Coursera, VoiceThread, Cloud classrooms, Google cardboard [18]. During the transition to the distance format, teachers pay a lot of attention and effort to adapt the educational trajectory to the online format, create online content, innovate, plan classes and gradually transfer students from a passive to an active role [19].

We assume that all this cannot but be reflected in the future post-pandemic period of returning to full-time education. The purpose of this study is to assess the prospects and give forecasts for the use of innovations that appeared and developed within the framework of distance learning during the pandemic in post-pandemic higher education. The objectives of the study were to analyze existing studies on this issue; to identify innovative technologies that could be successfully used in the post-pandemic period; make a forecast on the use of ICT and innovative technologies after the pandemic.

\section{Methods}

Methods of analysis, deduction, comparison, experiment and forecasting were used to solve the tasks set. The analysis of existing studies, deduction and comparison of innovations used in distance learning during the pandemic with innovations that appeared in pre-pandemic higher education, as well as the method of empirical experiment with the introduction of innovative technologies that entered pedagogical practice during distance learning, when returning to full-time training, allowed us to make a forecast of the development of higher education and the use of innovative and distance technologies in the post-pandemic period.

\section{$3 \quad$ Results}


The necessity to use new digital educational technologies has led to the spread of a flexible approach to learning [20]. During the pandemic, hybrid forms of education began to be actively used around the world, and asynchronous learning methods started to be applied along with synchronous education technologies [21]

Thus, in terms of using the experience of organizing the educational process during the global COVID-19 pandemic in higher education in the post-pandemic period, the transition to the use of hybrid (mixed) learning formats that combine the advantages of full-time and distance (online) forms of education can become an innovation.

In particular, for the organization of such a format of training in higher education institutions, it can be carried out:

1) the use of remote lecture formats;

2) the use of online whiteboards, video conferences, virtual and augmented reality technologies for conducting seminars;

3 ) the use of remote technologies for organizing the educational process, allowing for intermediate monitoring of academic performance, organizing independent work of students, etc. (for example, developed on the basis of the Moodle training course management system);

4) the use of interactive online learning technologies (tests, training games, online platforms with the possibility of discussion and commenting on, etc.).

At the same time, the introduction of the mentioned distance learning technologies in post-pandemic higher education should complement, and not exclude, the use of traditional teaching methods. In particular, it is critically important to preserve the hours of face-to-face consultations with the teacher, the opportunity to meet with the teacher to discuss issues of writing student research and other forms of personal communication with students. In addition, practical classes should be conducted mainly in full-time form, which are built on direct communication between students within the group, as well as with the teacher.

One of the main directions of the introducing such a hybrid learning format can be the teaching of foreign languages, within which a variety of online platforms have already been developed and are functioning, using modern digital learning technologies (solving interactive tests, passing mini-games, watching videos and listening to audio materials with built-in tasks, etc.), as well as creating opportunities for communication with native speakers of the language being studied (which is not always possible within the framework of traditional training). Such a format has already created the opportunity for a flexible and individual approach to training, which positively affects the level of student involvement [22].

For the post-pandemic period, the spread of such an approach to the organization of the educational process can be a serious step in terms of increasing the availability of education for people with disabilities, as well as other persons (for example, foreign students) who, for one reason or another, cannot systematically attend educational institutions and take a full part in the traditional educational process [23]. Besides, the introduction of asynchronous distance education practices possesses a high potential for improving the quality of education in higher education institutions as a whole [24].

\section{Discussion}

In order to adapt to the new requirements of our time, it is obvious that teachers need to improve their skills not just in the field of computer literacy, but in the field of specific educational platforms and software that allows them to conduct remote and hybrid classes, 
as well as create their own online courses. Thus, the Financial University under the Government of the Russian Federation (Moscow) in the 2020/2021 academic year conducted training of teachers using the Moodle system, which is planned to be actively used in the educational process both in the distance format and when leaving it. There is also a demand to reevaluate the curricula and syllabi of disciplines that would be more flexible and adaptive to different forms of learning and situations [25].

The researchers, without detracting from the merits of distance education and teachers in this difficult epidemiological situation, believe that the transfer of full-time classes to remote classes with the preservation of their structure cannot be a solution in the long term [15], and even if the remote format is preserved, significant changes are necessary. Thus, it is necessary to shift the focus from the teacher to the students, which can be expressed in group activities, discussions, practical classes [26]. It implies a review of the teacher's role and the connections in the system "a teacher - a student - an educational material" [27].

The researchers also identify the following possible forms of conducting classes in the post-pandemic period:

- hybrid classes, where either a certain percentage of students are present in person, or at will, the rest are taught synchronously remotely [28];

- HyFlex format (Hybrid + Flexible), in which each student decides for himself which parts of the course he takes remotely, and which are full-time, and to what extent [29, 30];

- Playlist Model, in which each student receives his own set of educational material in the right order and studies it at a convenient time, and after that full-time seminars or consultations are possible in person or in groups [31].

\section{Conclusion}

The most promising format for using the innovations of the pandemic period in post-pandemic higher education is a hybrid, or a mixed training format, in which both traditional and innovative educational technologies are used.

In our opinion, within the framework of this format, such methods of distance learning should be used: remote lecturing; the use of online whiteboards, online video conferences, virtual and augmented reality technologies for conducting seminars; interactive online learning technologies (tests, games, interactive video and audio materials, computer modeling, etc.); remote technologies for organizing the educational process that allow students to send educational materials, to carry out the intermediate monitoring of academic performance, to organize independent work, etc.

At the same time, such technologies of full-time education as personal consultations with the teacher, personal communication with the supervisor of student research projects and works, interactive practical classes (business games, debates, discussions), as well as a number of other technologies that are built on direct communication should be preserved.

\section{References}

1. Making the Most of Technology for Learning and Training in Latin America, in OECD Skills Studies (OECD, 2020). https://doi.org/10.1787/ce2b1a62-en

2. L. Ayuso, F. Requena, O. Jiménez, N. Khamis, J Compar Family Stud, 51(3-4), 274-287 (2020). https://doi.org/10.3138/jcfs.51.3-4.004

3. J. Carbonell, La aventura de innovar. El cambio en la escuela [The adventure of innovation. Change at school] (Ed. Morata, 2006) 
4. M. García, J. Reyes, G. Godínez, RICSH, 6(12), 299-316 (2018). https://doi.org/10.23913/ricsh.v6i12.135

5. S. Navarro Hudiel Tendencias en el uso de recursos y herramientas de la tecnología educativa en la educación universitaria ante la pandemia COVID-19 // Revista Ciencia Y Tecnología El Higo, 10 (2) (2020), pp. 111-122. https://doi.org/10.5377/elhigo.v10i2.10557

6. C.S. Varguillas, P.C. Bravo, Revista Cien Soc (Ve), XXVI(1), 219-232 (2020)

7. P.C. Torres, J.K. Cobo, Edu: Revista Venezolana Edu, 68, 31-40 (2017)

8. C. A. Gutiérrez-Rodríguez Fortalecimiento de las competencias de interpretación y solución de problemas mediante un entorno virtual de aprendizaje // Revista de Investigación, Desarrollo e Innovación, 8 (2) (2018), pp. 279-293.M. Guitert, M. Pérez-Mateo, Teoría Edu. Edu Cultura Soc Inf, 14(1), 10-31 (2013)

9. A. Anso, L. Magallan, M. Vallejos, ¿Actividades grupales en cursos virtuales? Desafios para el rol docente [Group activities in virtual courses? Challenges for the teaching role], in G. Feierherd (ed), XI Congreso de Tecnología en Educación y Educación en Tecnología (TEyET 2016), 494-501 Facultad de Informática Ciencias de la Comunicación y Técnicas Especiales, Universidad de Morón. 9-10 de junio de 2016 (Argentina, 2016)

10. J. Silva Un modelo pedagógico virtual centrado en las E-actividades // Revista de Educación a Distancia, 17 (53) (2017), pp. 1-20, URL: https://revistas.um.es/red/article/view/290021

11. T.A. Goroshnikova, E.S. Smakhtin, Mezhdistsiplinarnyi podkhod k uchebnoi programme kak universitetskii komponent dlya krupnomasshtabnykh obrazovatelnykh proektov [Interdisciplinary Curriculum Approach as a University Component for Large-scale Education Projects], in Proceedings of 2018 11th International Conference; Management of Large-Scale System Development, MLSD (2018). https://doi.org/10.1109/MLSD.2018.8551932

12. I.I. Klimova, G.V. Klimova, S.A. Dubinka, XLinguae, 12(1), 207-218 (2019)

13. C. Hodges, S. Moore, B. Lockee, T. Trust, A. Bond, La diferencia entre la enseñanza remota de emergencia y el aprendizaje en línea [The difference between emergency remote teaching and online learning] (2020). Accessed on: October 11, 2021. [Online]. Available:

https://er.educause.edu/articles/2020/3/the-difference-between-emergency-remote-teac hing-and-online-learning

14. L. García Aretio, RIED, 24(1) (2021). https://doi.org/10.5944/ried.24.1.28080

15. B.K. Wiederhold Connecting Through Technology During the Coronavirus Disease 2019 Pandemic: Avoiding "Zoom Fatigue" // Cyberpsychology, Behavior, and Social Networking, 23 (7) (2020), https://doi.org/10.1089/cyber.2020.29188.bkw

16. E. Winter, A. Costello, M. O’Brien, G. Hickey, Irish Edu Stud (2021). https://doi.org/10.1080/03323315.2021.1916559

17. D. Vargo, L. Zhu, B. Benwell, Zh. Yan, Human Behav Emerg Tech, 3(1), 13-24 (2020). https://doi.org/10.1002/hbe2.242

18. L. Sun, Y. Tang, W. Zuo, Nature Mater, 19(6), 687-687 (2020)

19. A. Schleicher, F. Reimers, Schooling Disrupted, Schooling Rethought: How the COVID-19 Pandemic is Changing Education (2020). Accessed on: October 11, 2021. 
[Online]. Available:

https://read.oecd-ilibrary.org/view/?ref=133_133390-1rtuknc0hi\&title=Schooling-disru ptedschooling-rethought-How-the-Covid-19-pandemic-is-changing-education

20. G. Marinoni, H. van't Land, T. Jensen, The impact of covid-19 on higher education around the world (International Association of Universities, 2020)

21. A. Gacs, S. Goertler, S. Spasova, Foreign Lang, 53, 380-392 (2020). https://doi.org/10.1111/flan.12460

22. S. Rashid, S.S. Yadav, Indian J Human Devel, 14(2), 340-343 (2020). https://doi.org/10.1177/0973703020946700

23. J.A. Bowen Teaching naked: How moving technology out of your college classroom will improve student learning. Hoboken: John Wiley \& Sons, 2012.

24. N. Johnson, G. Veletsianos, J. Seaman, Online Learn, 24(2) (2020). https://doi.org/10.24059/olj.v24i2.2285

25. X. Zhu, J. Liu, Postdig Sci Edu, 1(5) (2020). https://doi.org/10.1007/s42438-020-00126-3

26. P. Jandrić, et al., Edu Philos Theory, 50(10), 893-899 (2018). https://doi.org/10.1080/00131857.2018.1454000

27. B. J. Beatty Hybrid-Flexible Course Design. Implementing student directed hybrid classes. Provo, Utah: EdTech Books (2019).

28. B. Beatty Transitioning to an Online World: Using HyFlex Courses to Bridge the Gap // C. Montgomerie y J. Seale (Eds.), Proceedings of ED-MEDIA 2007-World Conference on Educational Multimedia, Hypermedia \& Telecommunications, Vancouver (2007), pp. 2701-2706. URL: https://www.learntechlib.org/primary/p/25752/

29. J. B. Miller, M. D. Risser, R. P. Griffiths Student Choice, Instructor Flexibility: Moving Beyond the Blended Instructional Model. Issues and Trends in Learning Technologies 1(1) (2013). doi: https://doi.org/10.2458/azu itet_v1i1_16464 